\title{
PENGARUH KINERJA KEUANGAN TERHADAP PENGUNGKAPAN \\ CORPORATE SOCIAL RESPONSBILITY (CSR) PADA \\ PERUSAHAAN MANUFAKTUR YANG TERDAFTAR \\ DI JAKARTA ISLAMIC INDEX PERIODA 2008-2012
}

\author{
Resti Yuliarni \\ Indah Kurniawati
}

\begin{abstract}
The purpose of this study was to determine how the effect of financial performance on the disclosure of corporate social responsibility (CSR). In this study the company's financial performance is measured using return on asset (ROA), net profit margin (NPM), current ratio $(C R)$, debt to equity ratio (DER), and inventory turnover (INTO). The sample used is secondary data from the Indonesia Stock Exchange (IDX) Annual Report ie companies listed in the Jakarta Islamic Index on the Stock Exchange in the year 2008-2012. Samples were taken by using purposive sampling method and sample selection criteria. The samples used were 38 companies. Based on the results of tests performed by test NPM and INTO variables significantly influence variable CSR disclosure. While going through the t test can be seen that the variable ROA, CR, and DER no significant effect on CSR disclosure. While based on simultaneous test (F test) ROA, NPM, CR, $D E R$, and INTO simultaneously having an influence on CSR disclosure. $R 2$ is the magnitude of 0.206. This suggests that the major effect of the independent variables are ROA, NPM, CR, DER and INTO the dependent variable is CSR disclosure can be explained by the model equations by $20.6 \%$ while the remaining $79.4 \%$ is influenced by other factors beyond research.
\end{abstract}

Keywords: Corporate social responsibility (CSR), return on asset (ROA), net profit margin (NPM), current ratio (CR), debt to equity ratio (DER), inventory turnover (INTO).

\section{PENDAHULUAN}

Kinerja adalah ukuran keberhasilan dari setiap bisnis. Selama ini dalam penilaian kinerja suatu perusahaan sebagian besar menggunakan analisis laporan keuangan. Analisis rasio keuangan yang lazim dipakai dalam penilaian kinerja suatu perusahaan dinyatakan dalam rasio keuangan yang terbagi menjadi empat kategori utama yaitu: (1) rasio likuiditas (liquidity ratio), yaitu rasio yang menunjukkan hubungan antara kas perusahaan dan aktiva lancar lainnya dengan 
hutang lancar; (2) rasio aktivitas (activity ratio), yaitu rasio yang mengukur efisiensi perusahaan dalam menggunakan aset-asetnya; (3) rasio leverage (leverage ratio), yaitu rasio yang mengukur seberapa banyak perusahaan menggunakan dana dari hutang (pinjaman) dan (4) rasio profitabilitas (profitability ratio), yaitu rasio yang menunjukkan kemampuan perusahaan untuk memperoleh keuntungan dari penggunaan modalnya (Martono dan Agus, 2008: 53).

Tuntutan terhadap perusahaan semakin besar karena selain dituntut untuk mengejar profit, perusahaan juga harus memperhatikan dan terlibat dalam pemenuhan kesejahteraan masyarakat serta turut aktif berkontribusi dalam menjaga kelestarian lingkungan. Tanggung jawab sosial perusahaan atau corporate social responsibility (CSR) merupakan sebuah gagasan yang menjadikan perusahaan tidak lagi dihadapkan pada tanggung jawab yang berpijak pada single bottom line, yaitu nilai perusahaan yang direfleksikan dalam kondisi keuangan perusahaan saja, tetapi tanggung jawab perusahaan harus berpijak pada triple bottom lines yaitu juga memerhatikan dimensi aspek keuangan, sosial dan lingkungan yang merupakan kunci dari konsep pembangunan berkelanjutan. Korporasi bukan lagi sebagai sebuah entitas bisnis yang hanya mementingkan pencapaian kinerja keuangan saja dengan memaksimalkan laba usahanya di tempat lingkungan sekitar perusahaan, melainkan sebuah entitas usaha yang wajib memperhatikan dan bertanggungjawab atas kegiatan operasi perusahaan yang memberikan dampak langsung terhadap lingkungan sekitarnya.

Suatu perusahaan yang mempunyai kinerja yang baik serta ukuran perusahaan yang besar sebaiknya melaksanakan tanggung jawab sosial perusahaan dan mengungkapnya secara terbuka kepada publik karena publik memandang bahwa kegiatan bisnis dari perusahaan sebagai kontributor terbesar terhadap permasalahan yang terjadi. Dorongan perusahaan untuk melaksanakan tanggung jawab sosial perusahaan didasari oleh Undang-Undang Pasal 74 Nomor 40 Tahun 2007 tentang Perseroan Terbatas yang menyebutkan bahwa tanggung jawab sosial dan lingkungan yang berlaku bagi perseroan yang mengelola/memiliki dampak terhadap 
sumber daya alam dan tidak dibatasi kontribusinya serta dimuat dalam laporan keuangan.

Berbagai penelitian tentang faktor-faktor yang mempengaruhi pengungkapan tanggung jawab sosial di Indonesia memunculkan hasil yang beragam. Premana (2011), Purnasiwi (2011), Kamil dan Antonius (2012) dalam penelitiannya menunjukkan hasil Profitabilitas tidak berpengaruh terhadap pengungkapan informasi sosial. Temuan ini sejalan dengan hasil yang diperoleh Hackston dan Milne (1996) dalam Sembiring (2003) yang tidak berhasil menemukan hubungan profitabilitas dengan pengungkapan informasi sosial. Sedangkan pada penelitian Fahrizqi (2010), Rahajeng (2010), Hartono, dkk (2011), Yintayani (2011), dan Sari (2012) menemukan bahwa profitabilitas berpengaruh positif dan signifikan terhadap pengungkapan tanggung jawab sosial perusahaan.

Beberapa penelitian tentang hubungan likuiditas terhadap pengungkapan tanggung jawab sosial yaitu Retrinasari dan Luciana (2007), Syahrir dan Susy (2010) menemukan bahwa likuiditas secara signifikan mempengaruhi kelengkapan pengungkapan laporan tahunan. Sedangkan Kamil dan Antonius (2012) tidak menemukan adanya pengaruh likuiditas terhadap pengungkapan CSR. Penelitian tersebut sejalan dengan penelitian yang dilakukan Rahajeng (2010) yang menemukan bahwa variabel likuiditas tidak berpengaruh terhadap pengungkapan tanggung jawab sosial perusahaan.

Penelitian-penelitian yang menghubungkan leverage dengan pengungkapan tanggung jawab sosial yaitu penelitian yang dilakukan oleh Yintayani (2011) dan Nur (2012) menemukan bahwa leverage berpengaruh negatif dan signifikan terhadap pengungkapan tanggung jawab sosial perusahaan. Sedangkan pada penelitian Cahya (2010) dan Purnasiwi (2011) variabel leverage berpengaruh positif dan signifikan terhadap pengungkapan tanggung jawab sosial perusahaan. Sedangkan Sembiring (2003) dan Fahrizqi (2010) menyatakan leverage tidak berpengaruh terhadap pengungkapan sosial perusahaan. Berdasarkan penelitianpenelitian tersebut, dapat diketahui bahwa faktor leverage belum konsisten sebagai 
faktor yang dapat mempengaruhi besar kecilnya tingkat pengungkapan sosial perusahaan. Berdasarkan uraian tersebut peneliti tertarik untuk melakukan penelitian mengenai pengaruh kinerja keuangan terhadap pengungkapan corporate social responsbility (CSR) pada perusahaan manufaktur yang terdaftar di Jakarta Islamic Index perioda 2008 - 2012.

\section{LANDASAN TEORI DAN PENGEMBANGAN HIPOTESIS}

\section{Pengungkapan Corporate Social Responsibility (CSR)}

Pengungkapan adalah pengeluaran informasi yang ditujukan bagi pihak-pihak yang berkepentingan. Tujuan dari pengungkapan tanggung jawab sosial perusahaan (corporate social responsibility disclosure) adalah agar perusahaan dapat menyampaikan tanggung jawab sosial yang telah dilaksanakan perusahaan dalam suatu perioda tertentu. Penerapan CSR dapat diungkapkan perusahaan dalam media laporan tahunan (annual report) perusahaan yang berisi laporan tanggung jawab sosial perusahaan dalam kurun waktu satu tahun berjalan.

Pengertian dari CSR telah dikemukakan oleh banyak pakar, di antaranya adalah definisi yang dikemukakan oleh Darwin (2004) dalam Anggraini (2006) mendefinisikan CSR sebagai mekanisme bagi suatu organisasi untuk secara sukarela mengintegrasikan perhatian terhadap lingkungan dan sosial ke dalam operasinya dan interaksinya dengan stakeholders, yang melebihi tanggung jawab organisasi di bidang hukum.

\section{Jakarta Islamic Index (JII)}

Jakarta Islamic Index (JII) merupakan salah satu indeks yang ada di Bursa Efek Indonesia (BEI). Indeks yang diluncurkan pada 3 Juli 2000 ditujukan untuk mengakomodasi para investor yang ingin berinvestasi di pasar modal pada saham yang sesuai dengan syariah. JII terdiri atas 30 jenis saham yang dipilih dari sahamsaham yang sesuai dengan syariah Islam. JII dimaksudkan untuk digunakan sebagai tolok ukur (benchmark) dalam mengukur kinerja suatu investasi pada saham dengan basis syariah. 


\section{Pengaruh Rasio Profitabilitas terhadap Pengungkapan Corporate Social Responsibility}

Profitabilitas perusahaan menunjukkan perbandingan antara laba dengan aktiva atau modal yang digunakan untuk menghasilkan laba tersebut, dengan kata lain profitabilitas adalah kemampuan perusahaan untuk menghasilkan laba selama perioda tertentu. Semakin tinggi tingkat profitabilitas perusahaan maka akan semakin besar pula pengungkapan informasi sosialnya (Hidayat, 2007 dalam Lawer dan Andreas, 2011). Donovan dan Gibson (2000) dalam Sembiring (2003) menyatakan bahwa berdasarkan teori legitimasi, salah satu argumen antara profitabilitas dan tingkat tanggung jawab sosial adalah bahwa ketika perusahaan memiliki tingkat laba yang lebih tinggi, perusahaan (manajemen) menganggap tidak perlu melaporkan hal-hal yang dapat mengganggu informasi tentang sukses keuangan perusahaan. Sebaliknya, pada saat tingkat profitabilitas rendah, mereka berharap para pengguna laporan akan membaca "good news" kinerja perusahaan, misalnya dalam lingkup sosial, dan dengan demikian investor akan tetap berinvestasi di perusahaan tersebut.

Penelitian Fahrizqi (2010), Rahajeng (2010), Yintayani (2011), Hartono, dkk (2011), serta Sari (2012) menemukan bahwa profitabilitas yang diukur dengan ROA berpengaruh terhadap pengungkapan tanggung jawab sosial perusahaan. Sedangkan pada penelitian Premana (2011), Purnasiwi (2011), Kamil dan Antonius (2012), serta Nur (2012) menemukan profitabilitas yang diukur dengan ROA tidak berpengaruh terhadap pengungkapan CSR.

Penelitian Anugerah, dkk (2010), Prastiti dan Sri (2011), serta Pribadi (2012) menemukan bahwa profitabilitas yang diukur dengan NPM berpengaruh terhadap pengungkapan tanggung jawab sosial perusahaan. Sementara itu, pada penelitian Retrinasari dan Luciana (2007) serta Syahrir dan Susy (2010) menemukan bahwa profitabilitas dengan proksi NPM tidak berpengaruh yang signifikan terhadap kelengkapan pengungkapan laporan tahunan. Berdasar penjelasan tersebut maka hipotesis yang diajukan adalah: 
$\mathrm{H}_{1}$ : Return on asset (ROA) berpengaruh terhadap pengungkapan CSR.

$\mathrm{H}_{2}$ : Net profit margin (NPM) berpengaruh terhadap pengungkapan CSR.

\section{Pengaruh Rasio Likuiditas terhadap Pengungkapan Corporate Social}

\section{Responsibility}

Likuiditas merupakan suatu indikator mengenai kemampuan entitas untuk membayar semua liabilitas finansial jangka pendek pada saat jatuh tempo menggunakan aset lancar yang tersedia. Tingkat likuiditas dapat dipandang dari dua sisi. Kesehatan suatu perusahaan yang dicerminkan dengan tingginya rasio likuiditas yang diukur dengan current ratio diharapkan berhubungan dengan luasnya tingkat pengungkapan informasi sosial perusahaan. Hal ini didasarkan bahwa kuatnya keuangan suatu perusahaan akan cenderung memberikan informasi yang luas dari pada perusahaan yang memiliki kondisi keuangan yang lemah. Tetapi sebaliknya, jika likuiditas dipandang sebagai ukuran kinerja, perusahaan yang mempunyai rasio likuiditas rendah perlu memberikan informasi yang lebih rinci untuk menjelaskan lemahnya kinerja dibanding perusahaan yang mempunyai rasio likuiditas yang tinggi (Rahajeng, 2010).

Penelitian Retrinasari dan Luciana (2007), Syahrir dan Susy (2010) menemukan bahwa likuiditas dengan proksi current ratio berpengaruh terhadap kelengkapan pengungkapan laporan tahunan. Penelitian Prayogi (2003) dan Suta (2012) menemukan current ratio berpengaruh secara signifikan terhadap tingkat pengungkapan sukarela. Sedangkan pada penelitian Sutomo (2004), Kamil dan Antonius (2012) dan Rahajeng (2010) menemukan bahwa Current Ratio tidak berpengaruh terhadap pengungkapan CSR. Dari penjelasan tersebut maka hipotesis yang diajukan adalah:

$\mathrm{H}_{3}$ : Current Ratio (CR) berpengaruh terhadap pengungkapan CSR. 


\section{Pengaruh Rasio Leverage terhadap Pengungkapan Corporate Social Responsibility}

Rasio leverage digunakan untuk memberikan gambaran mengenai struktur modal yang dimiliki perusahaan, sehingga dapat dilihat tingkat resiko tak tertagihnya suatu utang. Oleh karena itu, perusahaan dengan rasio leverage yang tinggi mempunyai kewajiban lebih untuk mengungkapkan tanggung jawab sosialnya. Menurut Lawer dan Andreas (2011) alasan yang mendasari adalah perusahaan yang tinggi debt ratio akan lebih mengungkapkan secara luas untuk memenuhi kebutuhan informasi krediturnya.

Penelitian yang berhasil menunjukkan hubungan antara Leverage dan CSR ini antara lain adalah penelitian Bange (2010), Cahya (2010), Premana (2011), Purnasiwi (2011), Yintayani (2011) dan Nur (2012) menemukan bahwa leverage yang diukur dengan proksi debt to equity ratio (DER) berpengaruh terhadap pengungkapan tanggung jawab sosial perusahaan. Sedangkan pada penelitian Sembiring (2003), Anugerah, dkk (2010), Fahrizqi (2010), Prastiti dan Sri (2011) dan Sari (2012) menemukan bahwa leverage yang diukur dengan proksi DER tidak berpengaruh terhadap CSR yang dilakukan perusahaan. Berdasar penjelasan tersebut maka hipotesis yang diajukan adalah:

$\mathrm{H}_{4}$ : Debt to equity ratio (DER) berpengaruh terhadap pengungkapan CSR.

\section{Pengaruh Rasio Aktivitas terhadap Pengungkapan Corporate Social Responsibility}

Rasio aktivitas dimaksudkan untuk mengukur seberapa besar keefektifan perusahaan dalam mengelola sumber-sumber dananya. Keefektifan perusahaan terpapar dari bagaimana perputaran seluruh aktiva perusahaan pada suatu perioda tertentu. Semakin tinggi rasio aktivitas menandakan kemampuan perusahaan yang expert dalam mengelola aktivanya. Hal ini memperlihatkan kondisi keuangan yang semakin stabil, kuat dan rendah resiko. Kondisi keuangan yang stabil dan kuat yang 
dihasilkan perusahaan, merupakan salah satu upaya perusahaan untuk mendapat dukungan stakeholders.

Pengelolaan aktiva yang baik, akan membawa perusahaan menuju kondisi/kinerja keuangan yang semakin baik dan kuat. Menurut Dilling (2009) mengemukakan bahwa terdapat beberapa penelitian hingga berkisar $70 \%$ yang menyebutkan hubungan positif antara kinerja keuangan dengan pengungkapan CSR. Pengelolaan aktiva yang baik akan mendorong manajer untuk mengungkapkan secara luas dalam kinerja keuangan perusahaan, salah satunya pengungkapan tanggung jawab sosial perusahaan. Penelitian terdahulu yaitu Sari (2013) tidak menemukan adanya pengaruh aktivitas dengan proksi inventory turnover terhadap pengungkapan sustainability report. Berdasar penjelasan tersebut maka hipotesis yang diajukan adalah:

H5: Inventory turnover berpengaruh terhadap pengungkapan CSR.

\section{Model Penelitian}

Variabel Independen

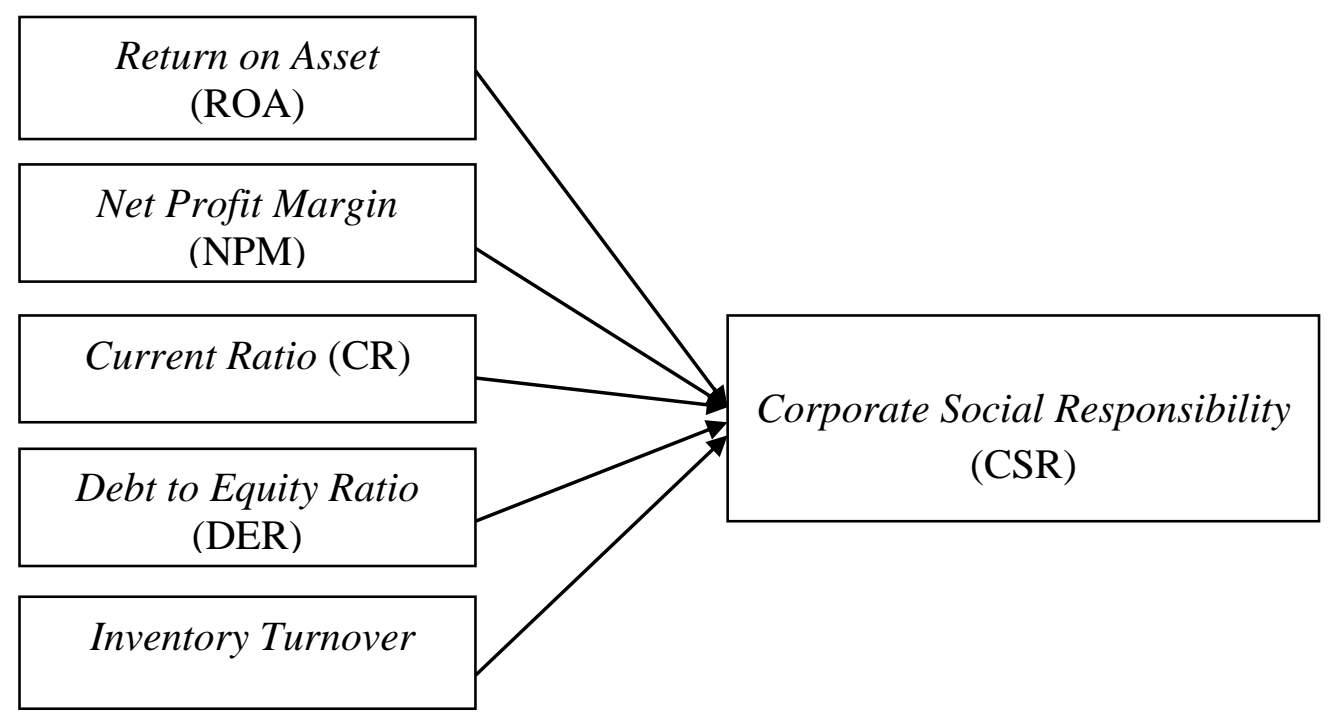

Gambar 1

Model Penelitian
Variabel Dependen

(CSR) 


\section{METODA PENELITIAN}

\section{Populasi dan Sampel}

Populasi penelitian ini adalah perusahaan-perusahaan yang terdaftar di Bursa Efek Indonesia perioda 2008-2012. Pemilihan sampel penelitian menggunakan metoda purposive sampling. Adapun kriteria yang digunakan untuk memilih sampel adalah sebagai berikut:

1. Perusahaan Manufaktur yang terdaftar dalam Jakarta Islamic Index di Bursa Efek Indonesia selama perioda 2008-2012.

2. Perusahaan menerbitkan dan mempublikasikan laporan tahunan (annual report) dan memiliki laporan keuangan serta harga saham lengkap selama perioda 2008-2012.

3. Perusahaan menerbitkan laporan tanggung jawab sosial dan/atau sustainability report selama perioda 2008-2012.

4. Memiliki data yang lengkap sesuai dengan variabel-variabel yang digunakan dalam penelitian.

Penelitian ini menggunakan data sekunder yang diperoleh dari laporan tahunan dan laporan keuangan perusahaan yang terdaftar dalam Jakarta Islamic Index selama perioda 2007-2011. Data diperoleh melalui website Bursa Efek Indonesia maupun website resmi masing-masing perusahaan.

\section{Definisi Operasional Variabel dan Pengukuran Variabel}

\section{Rasio Profitabilitas}

Profitabilitas diartikan sebagai kemampuan perusahaan untuk menghasilkan laba atau profit dalam upaya meningkatkan nilai pemegang saham. Variabel profitabilitas dalam penelitian ini menggunakan return on asset (ROA) dan net profit margin (NPM). Adapun pengukurannya dengan menggunakan rumus:

$$
\mathrm{ROA}=\frac{\text { Laba Bersih Setelah Pajak }}{\text { Total Aset }} \times 100 \%
$$




$$
\mathrm{NPM}=\frac{\text { Laba Bersih Setelah Pajak }}{\text { Penjualan Bersih }} \times 100 \%
$$

\section{Rasio Likuiditas}

Likuiditas adalah kemampuan perusahaan untuk memenuhi kewajiban atau utang jangka pendek tepat pada waktunya. Likuiditas dalam penelitian ini diukur dengan current ratio. Adapun pengukurannya dengan menggunakan rumus:

$$
\text { Current Ratio }=\frac{\text { Aset Lancar }}{\text { Kewajiban Lancar }} \text { X 100\% }
$$

\section{Rasio Leverage}

Rasio leverage menunjukkan seberapa besar kebutuhan dana perusahaan dibelanjai dengan hutang (Sutrisno, 2009:217). Penelitian ini menggunakan debt to equity ratio (DER) untuk mengukur leverage. Adapun pengukurannya dengan menggunakan rumus:

$$
\text { DER }=\frac{\text { Total Kewajiban }}{\text { Modal Sendiri }} \times 100 \%
$$

\section{Rasio Aktivitas}

Rasio aktivitas menunjukkan tingkat aktivitas atau efisiensi penggunaan dana yang tertanam pada pos-pos aktiva. Penelitian ini menggunakan inventory turnover untuk mengukur rasio aktivitas. Adapun pengukurannya dengan menggunakan rumus:

$$
\text { Inventory Turnover }=\frac{\text { Penjualan }}{\text { Persediaan }}
$$

\section{Corporate Social Responsibility (CSR)}

Variabel dependen yang digunakan adalah pengungkapan CSR perusahaan. Pengungkapan informasi sosial dikelompokkan menjadi 6 kelompok sesuai dengan 
kategori informasi sosial menurut Global Reporting Intiatives (GRI) (2000-2006) yang telah disesuaikan dengan pelaksanaan CSR di Indonesia. Adapun rumus untuk menghitung indeks pengungkapan CSR menurut kategori GRI sebagai berikut:

$$
\mathrm{CSRI}=\frac{\sum \mathrm{Xij}}{\mathrm{Nj}}
$$

Keterangan:

CSRI : Corporate Social Responsibility Index Perusahaan

$\mathrm{X}_{\mathrm{ij}} \quad$ : Jumlah Item CSR yang diungkapkan oleh perusahaan

$\mathrm{N}_{\mathrm{j}} \quad$ : Jumlah Item pengungkapan CSR yang standar

\section{ALAT ANALISIS DATA}

\section{Analisis Deskriptif}

Populasi dalam penelitian ini berjumlah 72 perusahaan, perusahaan yang termasuk dalam sektor manufaktur sebanyak 12 perusahaan. Perusahaan sektor manufaktur yang merupakan sampel dalam penelitian ini sebanyak 11 perusahaan, karena perusahaan tersebut masuk kedalam kriteria yang telah ditentukan dalam teknik pengambilan sampel dengan menggunakan teknik purposive sampling.

\section{Uji Asumsi Klasik}

\section{Uji Normalitas}

Uji normalitas data bertujuan untuk menguji apakah model regresi ditemukan adanya korelasi antar variabel independen.

\section{Uji Multikolinearitas}

Uji multikolinearitas bertujuan untuk menguji apakah model regresi ditemukan adanya korelasi antar variabel bebas (independen). Model regresi yang baik seharusnya tidak terjadi korelasi di antara variabel independen (Ghozali, 2012:105). 


\section{Uji Autokorelasi}

Uji autokorelasi digunakan untuk menguji apakah dalam model regresi linear ada korelasi antara kesalahan pengganggu pada perioda $t$ dengan kesalahan pengganggu pada perioda t-1 (sebelumnya).

\section{Uji Heteroskedastisitas}

Uji heteroskedastisitas digunakan untuk menguji apakah dalam model regresi terjadi ketidaksamaan variance dari residual satu pengamatan ke pengamatan yang lain (Ghozali, 2012:139). Pengujian heteroskedastisitas dalam penelitian ini menggunakan uji Glejser.

\section{Analisis Regresi Linear Berganda}

Pengujian hipotesis penelitian ini menggunakan metoda statistik analisis regresi linear berganda (multiple regression) dengan model persamaan sebagai berikut:

$$
\mathbf{Y}=\alpha+\beta \mathbf{x}_{1}+\beta \mathbf{x}_{2}+\beta \mathbf{x}_{3}+\beta \mathbf{x}_{4}+\beta \mathbf{x}_{5}+\mathbf{e}
$$

Keterangan:

Y : Corporate Social Responsibility Index Perusahaan

$\alpha$ : Bilangan konstanta

$\beta$ : Koefisien regresi

$\mathrm{x}_{1}$ : Return on asset (ROA)

$\mathrm{x}_{2}:$ Net profit margin (NPM)

$\mathrm{x}_{3}:$ Current ratio (CR)

$\mathrm{x}_{4}$ : Debt to equity ratio (DER)

$\mathrm{x}_{5}$ : Inventory turnover (INTO)

e : Kesalahan Penganggu 


\section{HASIL DAN PEMBAHASAN}

\section{Uji Normalitas}

Nilai Asymp. Sig (2-tailed) yang diperoleh dari hasil pengujian normalitas yaitu $>0,05$. Hal ini berarti model regresi dalam penelitian ini berdistribusi normal.

Tabel 1

Uji Normalitas

\begin{tabular}{|l|c|c|}
\hline \multicolumn{1}{|c|}{ Keterangan } & $\begin{array}{c}\text { Unstrandardized } \\
\text { Residual }\end{array}$ & $\begin{array}{c}\text { Tingkat } \\
\text { Kepercayaan (a) }\end{array}$ \\
\hline $\mathrm{N}$ & 38 & \multirow{2}{*}{0,05} \\
\cline { 1 - 2 } Kolmogorov-Smirnov $Z$ & 1,116 & \\
\cline { 1 - 2 } Asymp. Sig. (2-tailed) & 0,165 & \\
\hline
\end{tabular}

Sumber: Data sekunder, diolah (2013)

\section{Uji Multikolinieritas}

Hasil pengujian multikolinieritas menunjukkan tidak terdapat variabel independen yang memiliki nilai tolerance $\leq 0,10$ dan nilai VIF $\geq 10$. Hal ini berarti tidak ada multikolinieritas antara variabel independen dalam model regresi.

Tabel 2

Uji Multikolinieritas

\begin{tabular}{|l|c|c|}
\hline \multirow{2}{*}{ Model } & \multicolumn{2}{|c|}{ Colinearity statistics } \\
\cline { 2 - 3 } & Tolerance & VIF \\
\hline 1 (Constant) & & \\
ROA & 0,382 & 2,620 \\
NPM & 0,315 & 3,170 \\
CR & 0,453 & 2,206 \\
DER & 0,328 & 3,046 \\
INTO & 0,708 & 1,412 \\
\hline
\end{tabular}

Sumber: Data sekunder, diolah (2013)

\section{Uji Autokorelasi}

Hasil pengujian autokorelasi menggunakan Durbin Watson test menunjukkan nilai DW 1,204 $(\mathrm{dl}) \leq 1,698(\mathrm{dw}) \leq 1,792(\mathrm{du})$, hal ini berarti tidak ada autokorelasi positif dan keputusan yang diambil terhadap $\mathrm{H}_{0}$ tidak ada. Berdasar hasil tersebut, dapat diketahui bahwa pada regresi tidak terjadi autokorelasi. 
Tabel 3

Uji Autokorelasi (Durbin-Watson Test)

\begin{tabular}{|c|c|c|c|}
\hline Model & Durbin-Watson & DL & Du \\
\hline 1 & 1,698 & 1,204 & 1,792 \\
\hline
\end{tabular}

Sumber: Data sekunder, diolah (2013)

Hasil uji autokorelasi pada tabel 4 yang dilakukan dengan menggunakan Run test menunjukkan nilai $\mathrm{Z}$ sebesar 0,000 dengan nilai Asymp. Sig. (2-tailed) 1,000. Karena nilai asymp. sig lebih besar dari tingkat signifikansi 0,05 maka $\mathrm{H}_{0}$ diterima. Berdasar hasil tersebut, dapat diketahui bahwa residual random (acak) atau pada regresi tidak terjadi autokorelasi.

Tabel 4

Hasil Uji Autokorelasi-Run Test

\begin{tabular}{|l|c|c|}
\hline \multicolumn{1}{|c|}{ Keterangan } & $\begin{array}{c}\text { Unstrandardized } \\
\text { Residual }\end{array}$ & $\begin{array}{c}\text { Tingkat } \\
\text { Kepercayaan ( } \boldsymbol{\alpha})\end{array}$ \\
\hline Total Cases & 38 & \multirow{2}{*}{0,05} \\
\hline Z & 0,000 & \\
\hline Asymp. Sig. (2-tailed) & 1,000 & \\
\hline
\end{tabular}

Sumber: Data sekunder, diolah (2013)

\section{Uji Heteroskedastisitas}

Uji heteroskedastisitas digunakan untuk menguji bahwa dalam model regresi terjadi ketidaksamaan variance dari residual satu pengamatan ke pengamatan yang lain (Ghozali, 2012:139). Pengujian heteroskedastisitas dalam penelitian ini menggunakan uji Glejser. Hasil pengujian menunjukkan nilai signifikansi kelima variabel independen $>0,05$, hal ini berarti model regresi tersebut tidak terdapat heteroskedastisitas. 
Tabel 5

Uji Heteroskedastisitas

\begin{tabular}{|l|c|c|}
\hline Keterangan & Signifikansi & Tingkat Kepercayaan $(\boldsymbol{\alpha})$ \\
\hline 1 (Constant) & 0,526 & \\
ROA & 0,732 & 0,05 \\
NPM & 0,512 & 0,05 \\
CR & 0,195 & 0,05 \\
DER & 0,316 & 0,05 \\
INTO & 0,732 & 0,05 \\
\hline
\end{tabular}

Sumber: Data sekunder, diolah (2013)

\section{Pengujian Hipotesis}

\section{Uji Koefosien Determinasi $\left(\mathbf{R}^{2}\right)$}

Hasil uji koefisien determinasi diperoleh nilai $R$ Square sebesar 0,206, hal ini berarti variabel-variabel independen dalam penelitian ini dapat menjelaskan variabel dependen sebesar 20,6\%, sedangkan sisanya 79,4\% dijelaskan oleh variabel lain yang tidak diteliti dalam penelitian ini.

Tabel 6

Uji Koefisien Determinasi

\begin{tabular}{|c|c|c|c|}
\hline Model & R & R Square & Adjusted $\boldsymbol{R}$ Square \\
\hline 1 Regresi & $0,560^{\mathrm{a}}$ & 0,314 & 0,206 \\
\hline
\end{tabular}

Sumber: Data sekunder, diolah (2013)

\section{Uji F}

Hasil uji $\mathrm{F}$ diperoleh nilai signifikansi $0,028<0,05$, hal ini berarti variabel ROA, NPM, current ratio, DER, dan inventory turnover secara simultan (bersamasama) berpengaruh terhadap pengungkapan corporate social responsibility.

Tabel 7

Uji Signifikansi Simultan (Uji Statistik F)

\begin{tabular}{|c|c|c|c|}
\hline Model & F & Signifikansi & Tingkat Kepercayaan ( $\boldsymbol{\alpha})$ \\
\hline 1 Regresi & 2,924 & $0,028^{\mathrm{a}}$ & 0,05 \\
\hline
\end{tabular}

Sumber: Data sekunder, diolah (2013) 
Uji t

Tabel 8

Uji Signifikansi Parameter Individual (Uji Statistik t)

\begin{tabular}{|c|c|c|c|c|}
\hline Keterangan & $\mathbf{t}$ & Signifikansi & $\begin{array}{c}\text { Tingkat } \\
\text { Kepercayaan }(\alpha)\end{array}$ & Keputusan \\
\hline 1 (Constant) & 0.470 & 0,642 & & \\
\hline ROA & $-1,696$ & 0,100 & 0,05 & H1 ditolak \\
\hline NPM & 3,016 & 0,005 & 0,05 & $\mathrm{H} 2$ diterima \\
\hline $\mathrm{CR}$ & $-0,775$ & 0,444 & 0,05 & H3 ditolak \\
\hline DER & $-0,145$ & 0,885 & 0,05 & H4 ditolak \\
\hline INTO & 2,162 & 0,038 & 0,05 & H5 diterima \\
\hline
\end{tabular}

Sumber: Data sekunder, diolah (2013)

\section{Pengaruh Return on Asset (ROA) terhadap Pengungkapan CSR}

Hasil pengujian secara parsial pada tabel 8 , menunjukkan nilai signifikansi 0,100 > 0,05 maka $\mathrm{H}_{1}$ ditolak. Hal ini berarti ROA perusahaan tidak berpengaruh terhadap pengungkapan CSR pada suatu perusahaan. Hasil penelitian ini menunjukkan bahwa perusahaan dengan tingkat ROA yang tinggi, yang berarti memiliki dana yang cukup untuk dialokasikan kepada kegiatan sosial dan lingkungan, belum tentu mengalokasikan dananya tersebut pada kegiatan sosial dan lingkungan sehingga tingkat pengungkapan pertanggungjawaban sosial yang dilakukan adalah rendah. Selain itu perusahaan yang mempunyai profitabilitas tinggi belum tentu lebih banyak melakukan aktivitas sosial karena perusahaan lebih berorientasi pada laba semata. Hasil penelitian ini sejalan dengan penelitian yang dilakukan Premana (2011), Purnasiwi (2011), Kamil dan Antonius (2012), dan Nur (2012) yang menemukan bahwa profitabilitas yang diukur dengan ROA tidak berpengaruh terhadap pengungkapan CSR.

\section{Pengaruh Net Profit Margin (NPM) terhadap Pengungkapan CSR}

Hasil pengujian secara parsial pada tabel 8 , menunjukkan nilai signifikansi $0,005<0,05$ maka $\mathrm{H}_{2}$ diterima. Hasil penelitian ini menunjukkan bahwa net profit margin perusahaan berpengaruh terhadap pengungkapan CSR pada suatu 
perusahaan. Hasil penelitian ini sejalan dengan teori agensi yang menyatakan bahwa perolehan laba yang semakin besar akan membuat perusahaan mengungkapkan informasi sosial yang lebih luas. Hal ini memberikan interpretasi bahwa perusahaan dengan profitabilitas yang tinggi dapat mengatasi timbulnya biaya-biaya atas pengungkapan CSR tersebut. Tingkat profitabilitas yang semakin tinggi mencerminkan kemampuan entitas dalam menghasilkan laba yang semakin tinggi, sehingga entitas mampu untuk meningkatkan tanggung jawab sosial, serta melakukan pengungkapan tanggung jawab sosialnya dalam laporan keuangan dengan luas. Hasil penelitian ini konsisten dengan hasil penelitian yang dilakukan Anugerah, dkk (2010), Prastiti dan Sri (2011), dan Pribadi (2012) yang menemukan bahwa profitabilitas yang diukur dengan NPM berpengaruh signifikan terhadap pengungkapan tanggung jawab sosial perusahaan.

\section{Pengaruh Current Ratio terhadap Pengungkapan CSR}

Hasil pengujian secara parsial pada tabel 8, menunjukkan nilai signifikansi 0,444 > 0,05 maka $\mathrm{H}_{3}$ ditolak. Hal ini menunjukkan bahwa current ratio suatu perusahaan tidak berpengaruh terhadap pengungkapan CSR suatu perusahaan. Menurut Sutomo (2004) alasan yang mendasari hasil pengujian ini adalah karena kurangnya perhatian dari stakeholder yang berkepentingan terhadap informasi keuangan, kurang memperhitungkan kualitas likuiditas entitas maka pada akhirnya tidak banyak mempengaruhi pengungkapan CSR. Selain itu, CSR bukan lagi menjadi sekedar kegiatan, tetapi CSR merupakan sebuah kewajiban bagi perusahaan yang berguna untuk menjaga kelangsungan hidup perusahaan. Sehingga semakin tinggi atau rendahnya tingkat likuiditas perusahaan tidak mempengaruhi besarnya tingkat pengungkapan CSR. Hasil penelitian ini sejalan dengan penelitian yang dilakukan Sutomo (2004), Kamil dan Antonius (2012), dan Rahajeng (2010) yang menemukan bahwa likuiditas yang diukur dengan current ratio tidak berpengaruh terhadap pengungkapan tanggung jawab sosial perusahaan. 


\section{Pengaruh Debt to Equity Ratio (DER) terhadap Pengungkapan CSR}

Dari hasil pengujian secara parsial pada tabel 8 , menunjukkan nilai signifikansi 0,885 > 0,05 maka $\mathrm{H}_{4}$ ditolak. Hal ini menunjukkan bahwa DER suatu perusahaan tidak berpengaruh terhadap pengungkapan CSR suatu perusahaan. Sesuai dengan teori agensi maka manajemen perusahaan dengan tingkat leverage yang tinggi akan mengurangi pengungkapan CSR yang dibuatnya agar tidak menjadi sorotan dari para debtholders. Namun hasil penelitian ini tidak mendukung teori agensi yang menyatakan hubungan negatif perusahaan yang mempunyai rasio leverage yang tinggi dengan pengungkapan CSR. Sehingga besar kecilnya rasio leverage suatu perusahaan tidak mempengaruhi besarnya pengungkapan CSR yang dilakukan perusahaan. Hubungan yang sudah terjalin baik dengan debtholders dan kinerja perusahaan yang baik bisa membuat debtholders tidak terlalu memperhatikan rasio leverage perusahaan, sehingga menjadikan hubungan leverage dengan pengungkapan CSR menjadi tidak signifikan. Hasil penelitian ini sesuai dengan penelitian Sembiring (2003), Anugerah, dkk (2010), Fahrizqi (2010), Prastiti dan Sri (2011) dan Sari (2012) yang menemukan bahwa leverage yang diukur dengan DER tidak berpengaruh terhadap CSR yang dilakukan perusahaan.

\section{Pengaruh Inventory Turnover terhadap Pengungkapan CSR}

Hasil pengujian secara parsial pada tabel 8 , menunjukkan nilai signifikansi $0,038<0,05$ maka hipotesis kelima diterima. Hasil penelitian ini menunjukkan bahwa besar kecilnya tingkat inventory turnover perusahaan akan mempengaruhi pengungkapan corporate social responsibility pada suatu perusahaan. Semakin tinggi rasio aktivitas menandakan kemampuan perusahaan yang expert dalam mengelola aktivanya. Pengelolaan aktiva yang baik, akan membawa perusahaan menuju kondisi/kinerja keuangan yang semakin baik dan kuat. Hasil penelitian ini sejalan dengan pendapat Dilling (2009) yang mengemukakan bahwa terdapat beberapa penelitian hingga berkisar tujuh puluh persen yang menyebutkan hubungan positif antara kinerja keuangan dengan pengungkapan CSR. Pengelolaan 
aktiva yang baik akan mendorong manajer untuk mengungkapkan secara luas dalam kinerja keuangan perusahaan, salah satunya pengungkapan tanggung jawab sosial perusahaan. Hasil penelitian ini tidak sesuai dengan penelitian yang dilakukan oleh Sari (2013) yang menemukan bahwa aktivitas yang diukur dengan INTO tidak berpengaruh terhadap pengungkapan sustainability report.

\section{SIMPULAN, KETERBATASAN, DAN SARAN}

Berdasar hasil analisis data dengan uji statistik dapat disimpulkan bahwa NPM dan inventory turnover berpengaruh terhadap pengungkapan CSR. Sedangkan ROA, current ratio dan DER tidak berpengaruh terhadap pengungkapan CSR.

Keterbatasan yang ada dalam penelitian ini adalah:

1. Terdapat unsur subjektivitas dalam menentukan indeks pengungkapan CSR. Hal ini dikarenakan tidak adanya ketentuan baku yang dapat dijadikan acuan sehingga penentuan indeks untuk indikator dalam kategori yang sama dapat berbeda untuk setiap penulis.

2. Penelitian ini hanya menggunakan perusahaan manufaktur yang terdaftar dalam Jakarta Islamic Index (JII) di BEI sebagai sampel sehingga hasil penelitian tidak dapat mewakili kondisi seluruh perusahaan.

3. Isi dari annual report yang terdaftar di website BEI ataupun di website masingmasing perusahaan yang terkait dengan variabel penelitian ini masih ada data yang kurang lengkap.

Berdasar keterbatasan yang ada, maka saran yang diberikan untuk penelirian selanjutnya adalah:

1. Penelitian selanjutnya dapat menggunakan cara pengungkapan CSR yang berbeda, sehingga bisa terjadi keberagaman penelitian.

2. Penelitian selanjutnya dapat menambah variabel independen yang terkait dengan pengungkapan CSR, seperti tipe industri, ukuran perusahaan, kepemilikan manajemen dan lain-lain. Mengingat 79,4\% dari nilai variabel dependen dijelaskan oleh variabel lain diluar penelitian ini. 
3. Penelitian selanjutnya dapat menggunakan sampel yang lebih luas misalnya seluruh perusahaan yang terdaftar di Bursa Efek Indonesia.

4. Penelitian selanjutnya dapat menambah tahun pengamatan yang lebih lama lagi.

\section{DAFTAR PUSTAKA}

Anggraini, Fr. Reni Retno. 2006. "Pengungkapan Informasi Sosial dan Faktorfaktor yang Mempengaruhi Pengungkapan Informasi Sosial dalam Laporan Tahunan (Studi Empiris pada Perusahaan-perusahaan yang Terdaftar di BEI)". Proceeding Simposium Nasional Akuntansi 9 (Agustus), hal. 1-21.

Anugerah, Rita , Roland Hutabarat, dan W. Faradilla. 2010. "Pengaruh Ukuran Perusahaan, Leverage dan Profitabilitas terhadap Pengungkapan Tanggung Jawab Sosial Perusahaan pada Perusahaan Manufaktur yang Listing di BEI”. Jurnal Ekonomi (Maret), hal. 66-78.

Bange, Yulfiani. 2010. Analisis Tingkat Leverage terhadap Pengungkapan Tanggung Jawab Sosial Perusahaan. Skripsi. Bandung: Universitas Komputer Indonesia.

Cahya, Bramantya Adhi. 2010. Analisis Pengaruh Kinerja Keuangan terhadap Tanggung Jawab Sosial Perusahaan (Corporate Social Responsibility) (Studi pada Bank di Indonesia Perioda Tahun 2007-2008). Skripsi. Semarang: Universitas Diponegoro.

Dilling. 2009. "Sustainability Reporting in A Global Context: What Are the Characteristics of Corporatons that Provide High Quality Sustainability Reports- An Empirical Analysis". International Business \& Economics Research Journal (Januari), hal. 19-30.

Fahrizqi, Anggara. 2010. Faktor-faktor yang Mempengaruhi Pengungkapan Corporate Social Responsibility (CSR) dalam Laporan Tahunan Perusahaan (Studi Empiris pada Perusahaan Manufaktur yang Terdaftar dalam Bursa Efek Indonesia). Skripsi. Semarang: Universitas Diponegoro. 
Ghozali, Imam. 2012. Aplikasi Analisis Multivariate dengan Program IBM SPSS 20, Ed. 6. Semarang: Universitas Diponegoro.

Global Reporting initiative (GRI) dan Pedoman Laporan Keberlanjutan, [Online]. Didapatkan: http://www.globalreporting.org/G3_RG_BahasaIndonesia1. pdf. [30 > Maret 2013]

Hartono, Vidiana Hastutik Is, Luciana Spica Almilia, dan Nurul Hasanah Uswati Dewi. 2011. "Faktor-faktor yang Mempengaruhi Pengungkapan Tanggung Jawab Sosial dan Dampaknya terhadap Kinerja Keuangan dan ukuran Perusahaan". Fokus Ekonomi (April), hal. 50-68

Kamil, Ahmad dan Antonius Herusetya. 2012. "Pengaruh Karakteristik Perusahaan terhadap luas Pengungkapan Kegiatan Corporate Social Responsibility". Media Riset Akuntansi (Februari), hal. 1-17.

Lawer, Chrystina dan Andreas. 2011. "Pengaruh Karakteristik Perusahaan Terhadap Pengungkapan Tanggung Jawab Sosial”. Jurnal Akuntansi.

Martono dan Agus Harjito. 2008. Manajemen Keuangan. Yogyakarta: Ekonisia UII.

Nur, Marzully. 2012. "Analisis Faktor-faktor yang Mempengaruhi Pengungkapan Corporate Social Responsibility di Indonesia (Studi Empiris Pada Perusahaan Berkategori High Profile yang Listing di Bursa Efek Indonesia)". Jurnal Nominal, hal. 22-34.

Prayogi. 2003. Pengaruh Karakteristik Perusahaan Terhadap Luas Pengungkapan Sukarela Laporan Keuangan Tahunan Perusahaan yang Terdaftar di Bursa Efek Jakarta. Tesis. Semarang: Universitas Diponegoro.

Prastiti, Sawitri Dwi, dan Sri Utami. 2011. "Pengaruh Karakteristik Perusahaan terhadap Social Disclosure". Jurnal Ekonomi Bisnis (Maret), hal. 63-69.

Premana, Angga Budi. 2011. Pengaruh Karakteristik Perusahaan terhadap Pengungkapan Tanggung Jawab Sosial dalam Laporan Tahunan Perusahaan Manufaktur pada Bursa Efek Indonesia. Skripsi. Semarang: Universitas Diponegoro. 
Pribadi, Riantono, 2012, Pengaruh Kinerja Lingkungan, Kinerja Keuangan dan Ukuran Perusahaan terhadap Corporate Social Responsibility (CSR) Disclosure pada Perusahaan Pertambangan yang Terdaftar di Bursa Efek Indonesia. Didapatkan: http://repository.gunadarma.ac.id [11 Juni 2013]

Purnasiwi, Jayanti. 2011. Analisis Pengaruh Size, Profitabilitas dan Leverage Terhadap Pengungkapan CSR pada Perusahaan yang terdaftar di Bursa Efek Indonesia. Skripsi. Semarang: Universitas Diponegoro.

Rahajeng, Rahmi Galuh. 2010. Faktor-faktor yang Mempengaruhi Pengungkapan Sosial (social Disclosure) dalam Laporan Tahunan Perusahaan (Studi Empiris pada Perusahaan Manufaktur di Bursa Efek Indonesia). Skripsi. Semarang: Universitas Diponegoro.

Retrinasari, Ikka dan Luciana Spica Almilia. 2007. "Analisis Pengaruh Karakteristik Perusahaan terhadap Kelengkapan Pengungkapan dalam Laporan Tahunan Perusahaan Manufaktur yang Terdaftar di BEJ". Proceeding Seminar Nasional Inovasi dalam Menghadapi Perubahan Lingkungan Bisnis (Juni), hal. 1-16.

Sari, Mega Putri Yustia. 2013. Pengaruh Kinerja Keuangan, Ukuran Perusahaan dan Corporate Governance terhadap pengungkapan Sustainability Report. Skripsi. Semarang: Universitas Diponegoro.

Sari, Rizkia Anggita. 2012, "Pengaruh Karakteristik Perusahaan terhadap Corporate Social Responsibility Disclosure pada Perusahaan Manufaktur yang Terdaftar di Bursa Efek Indonesia". Jurnal Nominal Volume I Nomor I, hal 124-140.

Sembiring, Eddy Rismanda. 2003. Pengaruh Karakteristik Perusahaan terhadap Pengungkapan Tanggung Jawab Sosial: Studi Empiris pada Perusahaan yang Tercatat (Go-public) di Bursa Efek Jakarta. Tesis. Semarang: Universitas Diponegoro.

Suta, Anita Yolanda. 2012. Analisis Faktor-faktor yang Mempengaruhi Luas Pengungkapan Informasi Sukarela Laporan Tahunan (Studi Empiris pada Perusahaan Manufaktur yang Terdaftar di Bursa Efek Indonesia Tahun 2008-2010). Skripsi. Semarang: Universitas Diponegoro. 
Sutomo, Ibnu. 2004. Pengaruh Rasio Likuiditas, Solvabilitas, Karakteristik Perusahaan Terhadap Luas Pengungkapan Sukarela pada Laporan Tahunan Perusahaan. Tesis. Semarang: Universitas Diponegoro.

Sutrisno. 2009. Manajemen Keuangan Teori, Konsep \& Aplikasi. Yogyakarta: Ekonisia UII.

Syahrir, R. K dan Susy Suhendra. 2010. The Effect of Company Characteristic to Disclosure Fittings of Miscellaneous Industry Sector Annual Reports which is Registered in IDX. Didapatkan: http//papers.gunadarma.ac.id [11 Juni 2013].

Yintayani, Ni Nyoman. 2011. Faktor-faktor yang Mempengaruhi Corporate Social Responsibility (Studi Empiris pada Perusahaan yang Terdaftar di Bursa Efek Indonesia Tahun 2009). Tesis. Denpasar: Universitas Udayana.

Undang-Undang Perseroan Terbatas Nomor 40 Tahun 2007: tentang Perseroan Terbatas. Jakarta, Indonesia. Penerbit PT Bhuana Ilmu Populer. 2007. 